\title{
Towards the European Union - Impact of FDI and Technological Change on Turkish Banking
}

\author{
Özlem Olgu \\ College of Administrative Sciences and Economics, Koc University, \\ Rumeli Feneri Yolu, Sariyer, Istanbul \\ Turkey
}

\section{Introduction}

Despite the fact that Turkey has the 17th largest economy in the world and the $6^{\text {th }}$ largest economy in the European Union (EU), its financial system is still relatively small compared to most of the EU countries (State Planning Organisation, 2009). Even though increased competition has been monitored over the last decade particularly due to removal of barriers on foreign entry into the Turkish banking sector, there are still doubts on Turkey's competitive strength with the EU countries. What is important is that financial performance of institutions has become a primary concern of investors, lenders, shareholders, and in particular to managers, in planning and controlling their activities. We believe, financial progress since the 2000-01 twin crises, enforcement of internationally accepted banking regulatory and supervisory standards, for instance Basel I and II, as well as implementation of macroeconomic reforms increased stability and trust in Turkey. We expect these developments to have positive impact on bank performances attracting foreign direct investment (FDI) to the banking sector and as a result increase transfer of know how and apllication of new technological advances.

Above all the most imperative occurrence, not only for Turkish banking but also for Turkey as a nation, is the declaration of it as an EU accession country in 2005. After more than four decades of long standing negotiations, Turkey finally became a candidate member of the EU and thus required to adjust its legislation and regulatory environment to that of the EU by adapting the EU acquis communautaire during the convergence process. ${ }^{1}$ The current government carried out a constitutional revolution: deepening and widening democratic freedoms, introducing minority rights for the Kurds and, above all, starting to subordinate

\footnotetext{
${ }^{1}$ One of the most important items in the acquis on financial institutions is the harmonization of capital adequacy regulations. The latest EU directive that sets out the capital adequacy framework is the Capital Adequacy Directive 3 (CAD 3). CAD 3, which took effect in 2007 and applied to all credit institutions in the EU, simply translates Basel II into EU legislation. The adaptation of a Basel II type regulatory framework for financial institutions by the EU facilitated Turkey's efforts to comply with this section of the acquis, as Turkish authorities already opt to implement Basel II provisions fully as of January 2008 for capital adequacy requirements. In fact, capital adequacy requirements in Turkey were already established inline with Basel I (adopted in 1989) and market risk was incorporated in the calculation of capital adequacy ratio in 2002.
} 
Turkey's army to civilian authority. In fact, the European project worked as a powerful engine of reform and helped glue together Turkey's political tribes. We believe the ultimate hope of EU membership is an important factor on augmented FDI and would make Turkey even more attractive for foreign investors in the near future. This is due to the fact that Turkey has a highly skilled and adaptable labor force, a large domestic market, and the advantage of geographic closeness to Europe, Middle East, Northern Africa, and Central Asia markets.

The Global Competitiveness Report 2007-2008 released by the World Economic Form listed Turkey in the $53^{\text {rd }}$ place among 131 countries in the overall ranking (six step going up from 2006). Moreover, Turkey is listed as the $13^{\text {th }}$ most attractive country in the world for FDI, thus it is not surprising to have approximately 53 per cent of total banking assets held by foreign investors (BRSA, 2007). Since 2005, numerous leading banks in the global arena, particularly with European origin, raised their shareholdings in large and medium sized Turkish commercial banks. For instance, 42 per cent stake of Turkiye Ekonomi Bankası (TEB) bought by France's BNP Paribas in 2005, followed by 89 per cent stake acquisition of Dişbank by Belgium's Fortis bank, 5.5 per cent share sale of Garanti Bankasi to the US General Electric Consumer Finance, and 50 per cent stake sale of Yapı Kredi Bankası to Italy's UniCredito.

Even though massive progress has been achieved in terms of foreign inflows over the recent years, Turkey still ranks as one of the bottom compared to the EU emerging countries. The 28.7 percent average share of foreign participation in the EU-27 as well as Bulgarian (93 per cent) and Romanian (94 per cent) banking sectors is well above the level in Turkey (24.8 per cent). This is supportive of the argument by Steinherr et al. (2004) that Eastern European countries did not have any historical commercial banking activity when they opened up their markets and the most efficient option of quickly transforming their banking system was to invite foreign banks as strategic investors. In contrast, Turkish banking sector has long been established with domestic banks and provides the foreign banks with one representative office in order to help manage their activities. Additionally, legal uncertainties, family ownership of private banks, and relationship lending practices in Turkey could be other concerns of foreign investors over the past decades.

This chapter contributes to the literature by implying that technology transfer associated with inward FDI yields higher bank productivity. More generally, analysing the dynamic effects of foreign presence may be important in seeking answers to some of the relevant questions about effects of FDI on host country banking industries and technology transfers. It is interesting to illustrate that even though research on transition economies has been growing, studies on Turkish banking sector lag far behind. None of the studies revised in the literature identified productivity differences among foreign invested and domestic banks in Turkey as well as not examining the most recent periods. What distinguishes this study from the rest in the literature is its comphrehensive analysis of issues specified in various individual studies. The literature is extended in this study by analysing the impact of foreign ownership on the DEA Malmquist productivity scores and its decomposed components. Hence, informtion on bank technical efficiency change (TEC), pure efficiency change (PEC), technological change (TC), scale efficiency change (SEC) as well as total factor productivity change (TFPC) over the analysis period would be valueable and may serve to inform the relative effect of increased FDI in the market as Turkey is considered as a potential EU member. 
This study focuses on 17 commercial banks operating in Turkey from which more than half of them received foreign investment since 2001. The 'first-stage' analysis has been introduced with an application of the input oriented DEA Malmquist index. The 'secondstage' analysis tests the impact of bank specific variables as well as several dummy vaiables on the decomposed DEA Malmquist index components following the studies by Delis et al. (2008), Mukerjee et al. (2001), Dogan \& Fauesten (2003), Pasiouras et al. (2007), and Lensink et al. (2008). Regarding foreign bank entry, we expect to find evidence that productivity of domestic banks have increased particularly due to developments in application of technological advances.

In the next section, long standing negotiations between the EU and Turkey as well as the probable outcome of Turkey' EU membership both in politcal and economic grounds is summarised. In section 3, a summary of relevant studies in the literature is introduced followed by description of the data in section 4 . Section 5 characterizes firstly the methodology of decomposing DEA-Malmquist productivity measures into its relevant components and secondly how the estimated bank TFP change scores as well its decomposed components are related to relevant bank specific factors in the second stage regressions. Section 6 summarises the empirical findings followed by conclusions in section 7 .

\section{Long-standing negotiations and impact of Turkey's probable EU membership}

The EU has gone through a massive enlargement process in 2004 by inclusion of ten new countries in its body followed by Romania and Bulgaria in 2007. Turkey attached particular importance to the EU's recent enlargement process for two main reasons: (i) playing an active role in the ex-Soviet bloc as a trade partner, and (ii) the Association Agreement between Turkey and the EU guarantees its full EU membership. In fact, Turkey was one of the first candidate countries applied to join the European Economic Community (EEC), in July 1959, shortly after its creation in 1958. The response from the EEC was a suggestion to establish an Association between the Republic of Turkey and the EEC, i.e. the Ankara Agreement (1963), until circumstances in Turkey permit its accession. ${ }^{2}$

After pursuing inward-oriented development strategies throughout the 1960s and 1970s, Turkey switched over to a more outward-oriented policy stance in 1980 aiming to integrate the country into the EU. Turkey applied for full membership in 1987, whilst received a response in 1990 stating that accession negotiations could not be undertaken at the time as the EU was engaged in major internal changes (adoption of the Single Market), and developments in Eastern Europe and the Soviet Union. However, the EU was prepared to extend and deepen economic relations with Turkey without rejecting the possibility of full membership at a future date and the Commission underpinned the need for a comprehensive cooperation program to facilitate integration of the two sides as well as finalizing the Customs Union by 1995.

\footnotetext{
2 The Ankara Agreement aimed at securing Turkey's full membership in the EEC through the establishment of a customs union in economic and trade mattters in three phases, which still constitutes the legal basis of the Association.
} 
At the Association Council of 29 April 1997, the EU reconfirmed Turkey's eligibility for membership and asked the Commission to prepare recommendations to deepen the TurkeyEU relations, while claiming that the development of this relationship depends on a number of issues relating to Greece, Cyprus and human rights. The Commission, however, excluded Turkey from the enlargement process in its report entitled "Agenda 2000" disclosed on 16 July 1997, which may be seen as a contradiction. The report granted that the Customs Union was functioning satisfactorily and that it had demonstrated Turkey's ability to adapt to the EU norms in many areas, whilst porposed a number of recommendations on liberalization of trade in services, consumer protection and a number of political issues as pre-conditions for moving the relations forward.

On December 10-11, 1999, the European Council meeting held in Helsinki produced a breakthrough in Turkey-EU relations, where Turkey was officially recognized as a candidate country for accession and signed an Accession Partnership with the EU. However, contrary to other candidate countries (EU-1033, Bulgaria and Romania), Turkey did not receive a timetable for accession. After the approval of the Accession Partnership by the Council and adoption of the Framework Regulation on February 26, 2001, the Turkish government announced on March 19, 2001, its own National Program for adoption of the acquis communautaire. Since then, progress toward accession continues along the path set by the National Program. At the December 2004 Cophenhagen European Council meeting, it was decided to launch negotiations with Turkey and establish a timetable for accession (European Commission, 2004b).

Turkey took a number of important steps towards this end, such as major review of the Turkish Constitution that thirty-four articles have recently been amended. The package of constitutional amendments covers a wide range of issues, such as improving human rights, strengthening the rule of law and restructuring of democratic institutions. In addition, numerous reform measures have been adopted in economic framework in line with the National Program. Even though the membership negotiations has been opened, great uncertainties continue to prevail about whether Turkey will be able to achieve its goal of accession to the EU. Some of these are in political grounds whilst the greatest uncertainty might be whether EU governments and societies are willing to accept a large but nonetheless a Muslim country as part of the EU.

In the case of EU membership, massive population of Turkey will make it the second largest country of the EU following Germany, whilst the population projections state that it will likely be the largest by 2025. Togther with Germany, they will account for almost 30 percent of the EU's population and the EU will then have seven large countries, that is, Germany, France, Italy, the UK, Poland, Spain and Turkey.

Referring to its massive population, Turkey will certainly impact strongly on the political dynamics both among large members and within the EU as a whole. At this point, we find it interesting to examine the likely direct impact of Turkey's EU membership on the European Council, Commision and Parliament. Table 2 sets out voting weights by population share in an EU-25, EU-27 and probable EU-28.

${ }^{3}$ EU-10 countries are; Slovenia, Slovakia, Malta, Cyprus, Latvia, Lithuania, the Czech Republic, Estaonia, Poland and Hungary. 


\begin{tabular}{|c|c|c|c|c|}
\hline Countries & 2003 & 2015 & 2025 & 2050 \\
\hline France & 60144 & 62841 & 64165 & 64230 \\
\hline Germany & 82476 & 82497 & 81959 & 79145 \\
\hline Italy & 57423 & 55507 & 52939 & 44875 \\
\hline Poland & 38587 & 38173 & 37337 & 33004 \\
\hline Spain & 41060 & 41167 & 40369 & 37336 \\
\hline UK & 59251 & 61275 & 63287 & 66166 \\
\hline Turkey & 71325 & 82150 & 88995 & 97759 \\
\hline Total EU-25 & 454187 & 456876 & 454422 & 431241 \\
\hline Total EU-27 & 484418 & 485692 & 481837 & 454559 \\
\hline Total EU-28 (incl Turkey) & 555743 & 567842 & 570832 & 552318 \\
\hline Turkey as \% of EU-28 & 12.8 & 14.4 & 15.5 & 17.7 \\
\hline
\end{tabular}

Source: Adapted by the author from UN population forecasts

Table 1. Population projections for Turkey and selective EU countries, 2003-2050

\begin{tabular}{lcccccc}
\hline \multicolumn{1}{c}{ Countries } & \multicolumn{2}{c}{ Share in EU-25, 2004 } & \multicolumn{2}{c}{ Share in EU-27, 2007 } & \multicolumn{2}{c}{ Share in EU-28, 2015 } \\
\hline & V.W & Seats & V.W & Seats & V.W & Seats \\
\cline { 2 - 7 } Germany & 18.1 & 99 & 16.9 & 98 & 14.5 & 82 \\
France & 13.2 & 78 & 12.9 & 78 & 11 & 64 \\
Italy & 12.6 & 78 & 11.4 & 78 & 9.7 & 64 \\
UK & 13 & 78 & 12.6 & 78 & 10.7 & 64 \\
Spain & 9 & 54 & 8.4 & 54 & 7.2 & 44 \\
Poland & 8.4 & 54 & 7.8 & 54 & 6.7 & 44 \\
Turkey & -- & -- & -- & -- & 14.4 & 82 \\
\hline
\end{tabular}

Source: Adapted by the author from UN World Population Division, World Population Prospects (2002) -V.W: Voting weights

Table 2. Voting weights and number of seats in the European Parliament

Assuming the EU agrees on 'double-majority' system of voting in the constitution, EU decisions will need a majority of two countries and population. In an EU-28, no proposal could be passed without the support of at least 15 member countries. In such a system, no single state can dominate; where population size has more power is through the ability to block decisions. If the threshold is set at 60 percent, then in the EU-25, Germany together with the UK and France can block decisions (with 44.3 percent of total population, or with Italy instead of the UK making 43.9 percent), though they cannot achieve this in an EU-28 (where they have 36.2 percent of population) unless the population majority is set to 65 percent (Hughes, 2004).

In the case of a EU-28, each of Turkey and Germany will have around 14.5 per cent of the vote. Even though they will be strong players, they can not block proposals even together but with a third large country. The largest 5 countries in an EU-28 will account for 60.3 per 
cent of the vote by population. This is only 3.4 per cent higher than the share of the 'big 4' countries in the EU-25 (where they have 56.9 per cent of the vote). So, Turkey will be an important powerful player and will add to the already complex set of alliances and blocking combinations that are possible. But in an EU-28, despite its size, it does not add strongly to the dominance of large countries. As the debate on voting power in the constitution shows, questions of power and votes are highly politically sensitive and negotiations for Turkey's accession will not be simple.

Moreover, given its size, Turkey will have a large impact on the European Parliament. Assuming the EU decides to keep a limit of 732 seats in the parliament, then all countries' allocations have to be reduced to avoid the accession of Turkey, Romania and Bulgaria adding 149 seats (99 (same as Germany), 33 and 17, respectively). If there was a simple proportionate reduction across all countries on the allocation of seats, Germany and Turkey would have 82 seats and 11.2 per cent share of the vote each (down from 13.5 per cent), France, Italy and the UK would have 64 seats representing 8.7 per cent of the vote each (down from 10.6 per cent), and Spain and Poland would have 44 seats and 6.0 per cent of the vote (down from 7.3 per cent).

From the economic perspective, the most important fact about Turkey is its low purchasing power parity (PPP) adjusted per capita income which is almost equal to those of Bulgaria and Romania but more complicated, and expected to create economic consequences for the EU. What is different from the current EU is that its largest members today - Germany, France, Italy and the UK - also have the largest economies. Political and economic dominance go together. However, this is not the case for Turkey. Moreover, Turkey's biggest problems are its high unemployment and inflation rates as well as current account deficit. But we should emphasize the high GDP growth and GDP per capita growth rates that can be accepted as indicators of good performance and promise of development in the near future.

From Turkey's perspective, the EU accession will grant numerous benefits. Actually, Turkey would not have to wait very long to start reaping the benefits of an eventual EU accession. With the opening of EU accession negotiations in October 2005, Turkey is likely to attract larger sums of FDI in the near future, which has already been experienced in the banking sector since 2005. The opening of EU negotiations acted as a strong signal that Turkey will eventually become a full member of the EU and would assure foreign investors that the Turkish economy will follow a stable growth path for the foreseeable future and the legal and judicial environment will improve across all relevant areas of the common acquis.

\subsection{Why does EU opposes to Turkey's membership?}

While the EU is working with Turkey to help it move forward in its probable EU membership, there are some who are concerned about this progress. Some of the main issues pointed out by the opposers can be summarised as follows:

First, Turkey's culture and values are different from those of the EU as a whole. In fact, Turkey's 99.8 percent Muslim population is too different from Christian-based Europe. However, the EU introduces this case in a very political manner and explains that the EU is not a religion-based organization and that 12 million Muslims currently live throughout the EU, Moreover, Turkey is a secular (a non-religion-based government) state, whilst needs to 
"Substantially improve respect for the rights of non-Muslim religious communities to meet European standards."

Secondly, another argument is based on the geographical fact that Turkey is mostly not in Europe, thus it should not become part of the EU. If that is the case what could be said about Cyprus? Is the island geographically located in Europe? This brings us to the third issue of Turkey's non-recognition of Republic of Cyprus, which is a full-fledged member of the EU since 2004. Additionally, many are concerned about the rights of Kurds in Turkey. The Kurdish people have limited human rights and there are accounts of genocidal activities that need to stop for Turkey to be considered for the EU membership.

Thirdly, Turkey is receiving considerable assistance from its European neighbors as well as from the EU. The EU has allocated billions and is expected to allocate billions of euros in funding for projects to help invest in a stronger Turkey that may one day become a member of the EU. The low per-capita income of the Turkish population is also of concern since the economy of Turkey as a new EU member might have a negative effect on the EU as a whole. From the EU's perspective, the most probable economic objections to Turkey's full membership can be listed as: (i) Turkey will receive a significant part of the EC structural funds and will impose an additional burden on countries that are major contributors to the Community budget; (ii) the Turkish economy is not mature enough for the single market, and the Turkish industry is not competitive with that of the EU, and (iii) there is also a problem of free movement of the labor force as Turkey will lead to a huge arrival of Turkish immigrants into the EU countries, particularly Germany.

Finally, some are concerned that Turkey's large population would alter the balance of power in the EU as discussed in the previous section of this chapter. After all, Germany's population, which is the largest country in the EU is only at 82 million and declining. Turkey would be the second largest country and perhaps eventually the largest with its much higher growth rate in the EU. Thus it would have considerable influence in the European Parliament.

\section{Literature survey}

Over the last decade several papers examined the relationship between foreign ownership and bank performances as well as the differences among foreign owned versus domestic banks. Even though there is an established literature on identifying the effects of FDI inflows and access to foreign capital on the productivity of non-financial institutions, such as Gorg \& Greenaway (2004) and Moran et al. (2005); empirical research analysing the impact of increased FDI on bank productivity is very narrow. Studies by Classens et al. (2001); Demirguc-Kunt \& Huizinga (2000); Berger \& Humphey (1997) and Berger et al. (2000) examined performance of domestic and foreign-owned banks offering little insight on how foreign existence influences bank productivity. Moreover, several studies in the literature test the impact of foreign ownership on bank efficiency, mainly using ownership dummies (see for instance, Lensink et al., 2008), although none can be found on the foreign ownership-bank productivity relationship.

A channel of the literature works on analysing sources of bank productivity differences across a sample of countries mainly focusing on country-specific economic, demographic and technological conditions (Chaffai et al, 2001); financial regulatory environment (Delis et 
al, 2008), success or failure of policy initiatives (Casu et al., 2004), and economic liberalization or financial deregulation (Berg et al, 1992; Dogan \& Fausten, 2003; Grifell-Tatje \& Lovell, 1997; Isik \& Hassan, 2003; Mukerjee et al, 2001; Tirtiroglu et al., 2005; Worthington, 1999). The general conclusion reached by Dietsch \& Lozano-Vivas (2000); Cavallo \& Rossi (2002); Lozano-Vivas et al. (2002); Pasiouras et al. (2007); Lensink et al. (2008) and Pasiouras (2008) is that country-specific environmental conditions and deregulatory policies are important factors on both bank productivity and efficiency.

In connection to the global advantage hypothesis introduced by Berger et al. (2000); Aitken \& Harrison (1999) proposed FDI as a factor negatively affecting domestic bank productivity. They stated that foreign banks may have a competition advantage due to their better resources and technologies resulting in greater market share with lower interest margins and risk premiums in a country than its domestic counterparts.

Another argument in the literature is on the cherry-picking aspect, i.e. foreign banks may magnify the risk profile of their domestic counterparts by using their financial power to pick the most rewarding features of the domestic market, and force domestic banks to do more risky business. Furthermore, domestic bank competitiveness and efficiency is achieved before rather than after the entry of foreign banks into the sector. In other words, efficiency is a pre-condition rather than a result of foreign bank entry. Berger et al. (2000) focused on this issue specifically examining the major industrialised countries and investigated whether the 'home-field advantage hypothesis' or the 'global-advantage hypothesis' holds.

This isuue has been examined by Hymer (1976) in an earlier study and illustrated that foreign firms are likely to face competitive disadvantages relative to national firms. This is due to the fact that domestic firms have the general advantage of better information about their country's economy, language, laws and politics. This leads to the hypothesis that foreign banks suffer more from a bad institutional framework in the host country than domestic banks. Foreigners and nationals may receive different treatment from governments, consumers and suppliers. In countries with a solid institutional framework, the impact of foreign ownership on bank efficiency will be less negative or more positive than in countries where the institutional framework is bad.

In another study, Mian (2006) develops a theoretical model on the effect of institutional distance on foreign bank behaviour. He assumes that institutional distance between the home country and the host country will cause higher informational, agency, or enforcement costs for foreign banks operating abroad. This issue has also been investigated by Stein (2002) who stated that technologies such as derivative contracts, ATM networks and Internet banking allow banks to interact efficiently with customers over long distances as well as improving the ability of senior headquarters managers to monitor junior managers working at distant locations.

In the case of US banking sector, Hancock et al. (1999) suggested that large financial institutions dominate electronic payments processing due to information-based scale economies. Moreover, Berger \& Mester (2003) confirmed the hypothesis that technological progress allows banks to offer wider varieties of services and banks engaging in merger activity had the greatest gains in profit productivity. This suggests that merger and acquisitions may allow foreign banks an opportunity to apply technological innovations in host countries. 
In the case of Turkey, changing economic and financial environment attracted attention of researchers. ${ }^{4}$ Oral \& Yolalan (1990) computed operating efficiency and profitability of bank branches and demonstrated service-efficient bank branches as the most profitable. In another study, Zaim (1995) evaluated the effects of liberalization policies on efficiency of Turkish commercial banks during the period of 1981 and 1990 and found that financial liberalization had a positive effect on both the technical and the allocative efficiencies, and public banks were more efficient than private counterparts. Similarly, Denizer, Dinc, \& Tarimcilar (2000) examined the bank efficiency during the pre and post-liberalization environment and investigated the scale effects on efficiency by ownership covering the 1970-1994 period. Findings suggested that liberalization programs were followed by an observable decline in efficiency and that the Turkish banking system had a serious scale problem due to macroeconomic instability.

Furthermore, Yildirim (2002) analysed efficiency performance of Turkish banks over the 1988-1999 period. The empirical results suggested that over the sample period both pure technical and scale efficiency measures showed a great variation, the sector could not achieve sustained efficiency gains and that the trend in the performance scores suggested a strong impact of macroeconomic conditions on the efficiency measures. Consistent with Denizer et al. (2000), Yildirim concluded that the sector suffered mainly from scale inefficiency due to decreasing return to scale (DRS). Confirming these findings Isik \& Hassan (2002) indicated that the dominant source of inefficiency in Turkish banking was due to technical inefficiency rather than allocative inefficiency, which was mainly attributed to diseconomies on scale. The results suggested that the heterogeneous characteristics of banks have significant impact on efficiency.

Yolalan (1996) used financial ratios to analyze the efficiency of the Turkish commercial banks over the period 1988-1995. The results showed that foreign banks were the most efficient group, followed by private and public banks respectively. Mercan, Reisman, Yolalan, \& Emel (2003) introduced a financial performance index on Turkish banks over the 1989-99 period, which allowed for observing effects of scale and mode of ownership on bank behaviour. They applied DEA to select fundamental financial ratios for the period of 19891999. The results showed that banks that were taken over by a regulatory government agency perform poorly with respect to their DEA performance index values.

\section{The data}

The data for this study comprise the population of 17 commercial banks operating in Turkey and concerns the 1992-2008 period, consisting of 272 observations, as available from the Bank Association of Turkey (BAT). The sample period is chosen as it covers financial structural changes, the most recent wave of FDI and opening up of EU negotiations.

Selection of inputs and outputs is guided by the objectives of the Turkish banking system, where commercial banks act as intermediaries with the objective of collecting deposits. Therefore, we use the Intermediation approach proposed by Sealey \& Lindley (1977), similar to many other studies, Zaim (1995), Kraft \& Tirtiroglu (1998), Rezvanian \& Mehdian (2002),

${ }^{4}$ There are couple of studies that analyse efficiency of Turkish banks applying DEA such as Oral and Yolalan (1990), Altunbas et al. (1994c), Zaim (1995), Denizer et al. (2000), and Isik and Hassan (2002). 
Isik \& Hassan $(2002,2003)$ and Havrylchyk (2006), where total assets, total deposits and total expenses (inclusing personnel expenses) are considered as inputs used to produce total loans and interest income as outputs. Table 3 introduces the sample characteristics.

\begin{tabular}{lcccc}
\hline \multicolumn{1}{c}{ Year } & Domestic & Foreign Invested & Total & Observations \\
\hline $1992-1996$ & 17 & 0 & 17 & 68 \\
$1996-2000$ & 17 & 0 & 17 & 68 \\
$2000-2004$ & 15 & 2 & 17 & 68 \\
$2004-2008$ & 8 & 9 & 17 & 68 \\
Total & 57 & 11 & 68 & 272 \\
\multicolumn{1}{c}{ Approach } & Outputs & Inputs & & \\
& Total loans & Total assets & & \\
Intermediation & Interest income & Total expenses & & \\
& & Total Deposits & &
\end{tabular}

\section{FDI Information}

\begin{tabular}{|c|c|c|c|c|}
\hline Year & Domestic Bank & Aquirer & $\begin{array}{l}\text { Origin of } \\
\text { Aquirer }\end{array}$ & $\begin{array}{c}\text { Stake Bought } \\
(\%)\end{array}$ \\
\hline 2001 & Demirbank & HSBC & UK & 100 \\
\hline 2002 & Koc Bank & UniCredit & Italy & 50 \\
\hline \multirow[t]{5}{*}{2005} & YKB & UniCredit/Kocbank & Italy-Turkey & 57 \\
\hline & TEB & BNP Paribas & France & 50 \\
\hline & Disbank & Fortis & Belgium & 89 \\
\hline & Garanti Bankasi & GE Capital Corporation & USA & 26 \\
\hline & Finansbank & $\begin{array}{l}\text { National Bank of } \\
\text { Greece }\end{array}$ & Greece & 46 \\
\hline \multirow[t]{3}{*}{2006} & Denizbank & Dexia Bank & Belgium & 75 \\
\hline & Sekerbank & BTA & Kazakhstan & 34 \\
\hline & Akbank & Citigroup & USA & 20 \\
\hline
\end{tabular}

Table 3. Sample characteristics

\section{Methodology: DEA-Malmquist index}

The nonparametric DEA-Malmquist index can be estimated by exploiting the relationship of distance functions to the technical efficiency measures developed by Farrell (1957). This technique is a "primal" index of productivity change. Therefore, it does not require cost or revenue shares to aggregate inputs and outputs, and was introduced to the literature by Caves et al, (1982a). In order to calculate Malmquist index, it is first required to define distance functions with respect to two different time periods, such as:

$$
D_{o}^{t}\left(\chi^{t+1}, y^{t+1}\right)=\inf \left\{\Theta:\left(\chi^{t+1}, y^{t+1} / \Theta\right)\right\} \in S^{t}
$$


Where $D_{o}$ is the distance function at time $t$ with $\chi^{t}$, Input vector in time $t+1$ and $y^{t}$, output vector in time $t+1$. Technical efficiency is indicated by $\Theta$ and production technology by $S t$. The distance function in equation (1) measures the maximal proportional change in outputs required to make $\left(\chi^{t+1}, y^{t+1}\right)$ feasible in relation to technology at $t$ (Fare, Grosskopf, Norris \& Zhang, referred to as FGNZ, 1994). Then, the Malmquist index reference to technology $t$ is defined by CCD (1982a) as:

$$
M_{C C D}^{t}=\frac{D_{o}^{t}\left(\chi^{t+1}, y^{t+1}\right)}{D_{o}^{t}\left(\chi^{t}, y^{t}\right)}
$$

whereas for period $\mathrm{t}+1$ it is:

$$
M_{C C D}^{t+1}=\frac{D_{o}^{t+1}\left(\chi^{t+1}, y^{t+1}\right)}{D_{o}^{t+1}\left(\chi^{t}, y^{t}\right)}
$$

In order to avoid choosing "an arbitrary benchmark", the output based Malmquist productivity index, $M_{0}$, is specified to be the geometric mean of equation (3). Then:

$$
M_{o}\left(\chi^{t+1}, y^{t+1}, \chi^{t}, y^{t}\right)=\left[\frac{D_{o}^{t}\left(\chi^{t+1}, y^{t+1}\right)}{D_{o}^{t}\left(\chi^{t}, y^{t}\right)}\right]\left[\frac{D_{o}^{t+1}\left(\chi^{t+1}, y^{t+1}\right)}{D_{o}^{t+1}\left(\chi^{t}, y^{t}\right)}\right]^{\frac{1}{2}}
$$

Following FGNZ (1994), the above formula can be decomposed into technical efficiency change and technological change thus:

$$
\begin{gathered}
M_{o}\left(\chi^{t+1}, y^{t+1}, \chi^{t}, y^{t}\right)=\left[\frac{D_{o}^{t}\left(\chi^{t+1}, y^{t+1}\right)}{D_{o}^{t}\left(\chi^{t}, y^{t}\right)}\right]\left[\left(\frac{D_{o}^{t}\left(\chi^{t+1}, y^{t+1}\right)}{D_{o}^{t+1}\left(\chi^{t+1}, y^{t+1}\right)}\right)\left(\frac{D_{o}^{t}\left(\chi^{t}, y^{t}\right)}{D_{o}^{t+1}\left(\chi^{t}, y^{t}\right)}\right)\right]^{\frac{1}{2}} \\
\begin{array}{c}
\text { Technical Efficiency } \\
\text { Change }
\end{array}
\end{gathered}
$$

The first figure in parenthesis measures the efficiency change, whereas the second one represents the technical change component of the index. There is productivity growth if $M_{o}$ $>0$, stagnation if $\mathrm{M}_{\mathrm{o}}=0$, and productivity decline if $\mathrm{M}_{\mathrm{o}}<0$. Given the fact that the Malmquist decomposition of FGNZ (1994) is based on CRS reference technology, no scale effect could be identified. Thus, FGNZ' catch-up component from the combination of efficiency change and scale efficiency change is inappropriate. In order to overcome this limitation Ray \& Desli (1997) developed a model which measures the correct productivity change by the ratio of constant returns to scale (CRS) distance functions even though the technology is variable returns to scale (VRS). The technological change component based on the VRS distance function could affect scale efficiency change while technical change 
remains unaffected. The scale efficiency change (SE) component is defined by the distance function as:

$$
S E^{t}\left(\chi^{t}, y^{t}\right)=\frac{D_{C R S}^{t}\left(\chi^{t}, y^{t}\right)}{D_{V R S}^{t}\left(\chi^{t}, y^{t}\right)}
$$

where, CRS represents reference technology with a constant returns to scale assumption and VRS a variable returns to scale assumption. However, Fare et al. (1997b) were the first to criticise the Ray \& Desli (1997) model as to the fact that it cannot measure scale efficiency change (S $\Delta$ ) since each component uses only single period technology (Lovell, 2001). Therefore, the equation has been extended to incorporate time and the scale efficiency change factor.

$$
\begin{aligned}
& S \Delta\left(x^{t}, y^{t}, x^{t+1}, y^{t+1}\right)= \\
& {\left[\frac{S E^{t}\left(x^{t+1}, y^{t+1}\right) / D_{0}^{t}\left(x^{t+1}, y^{t+1}\right)}{S E^{t}\left(x^{t}, y^{t}\right) / D_{0}^{t}\left(x^{t}, y^{t}\right)} * \frac{S E^{t+1}\left(x^{t+1}, y^{t+1}\right) / D_{0}^{t+1}\left(x^{t+1}, y^{t+1}\right)}{S E^{t+1}\left(x^{t}, y^{t}\right) / D_{0}^{t+1}\left(x^{t}, y^{t}\right)}\right]^{\frac{1}{2}}}
\end{aligned}
$$

Then the Malmquist productivity index $\left(\mathrm{M}_{\mathrm{o}}\right)$ can be decomposed into technical efficiency change and technological change written in the first paranthesis and scale efficiency change in the latter as:

$$
M_{o}=\left[\frac{D_{V R S}^{t}\left(\chi^{t+1}, y^{t+1}\right)}{D_{V R S}^{t}\left(\chi^{t}, y^{t}\right)} \times \frac{D_{V R S}^{t+1}\left(\chi^{t+1}, y^{t+1}\right)}{D_{V R S}^{t+1}\left(\chi^{t}, y^{t}\right)}\right]^{\frac{1}{2}} \times\left[\frac{S E^{t}\left(\chi^{t+1}, y^{t+1}\right)}{S E^{t}\left(\chi^{t}, y^{t}\right)} \times \frac{S E^{t+1}\left(\chi^{t+1}, y^{t+1}\right)}{S E^{t+1}\left(\chi^{t}, y^{t}\right)}\right]^{\frac{1}{2}}
$$

where $D_{0}$ is the distance function with input vectors of $X^{t}$ and $X^{t+1}$ for periods $t$ and $t+1$ and output vectors of $Y^{t}$ and $Y^{t+1}$ for periods $t$ and $t+1$, respectively. $D_{V R S}{ }^{t}$ and $D_{V R S}{ }^{t+1}$ represent technologies with variable returns to scale at periods $t$ and $t+1$ and $\mathrm{SE}^{t}$ and $\mathrm{SE}^{\mathrm{t}+1}$ are variables identifying scale efficiency change at periods $t$ and $t+1$. An improvement in TC is considered as a shift in the frontier. Also, scale efficiency change (SEC) component has been subject to a number of criticisms (see Casu et al., 2004), mainly in terms of the role of constant returns vs. variable returns to scale frontiers. However, there seems to be consensus that the Malmquist index is correctly measured by the constant returns to scale distance function, even when technology exhibits variable returns to scale.

\section{Empirical findings}

Throughout this section, we present input oriented Malmquist Index findings obtained by the DEAP software introduced by Coelli (1996), using a panel of Turkish commercial banks with a total of 272 observations over the period 1992-2008. As aforementioned, TFPC scores are decomposed into TC, TEC, PEC and SEC components. At this stage, it may be questionable to assume that all banks are coming from the same legal and business environment and pool domestic and foreign invested banks together. As a robustness check, we performed parametric (ANOVA) and non-parametric (Wilcoxon and Kruskal-Wallis) 
tests to check the null hypothesis that all banks come from the same population following Isik \& Hasan (2002), and Havrylchyk (2006). Results of the tests are presented in Table 4. Consistent with Sathye (2001), and Isik \& Hassan $(2002,2003)$ tests could not reject the null hypothesis at $1 \%$ significance level, thus foreign invetsed and domestic commercial banks are from the same sample and it would be appropriate to pull all banks together using a common frontier.

\begin{tabular}{|c|c|c|c|}
\hline Test statisticsa & $\begin{array}{c}\text { ANOVA } \\
\mathrm{F}(\text { prob>F) }\end{array}$ & $\begin{array}{l}\text { Wilcoxon } \\
\mathrm{z} \text { (prob>z) }\end{array}$ & $\begin{array}{c}\text { Krusal-Wallis } \\
\chi^{2}\left(\text { prob }>X^{2}\right)\end{array}$ \\
\hline \multicolumn{4}{|l|}{ Panel A: 1992} \\
\hline TEC & $\begin{array}{c}0.664 \\
(0.112)\end{array}$ & $\begin{array}{c}0.536 \\
(0.212)\end{array}$ & $\begin{array}{l}0.158 \\
(0.00)\end{array}$ \\
\hline $\mathrm{TC}$ & $\begin{array}{c}0.749 \\
(0.230)\end{array}$ & $\begin{array}{c}0.344 \\
(0.032)\end{array}$ & $\begin{array}{l}0.208 \\
(0.00)\end{array}$ \\
\hline PEC & $\begin{array}{c}0.663 \\
(0.162)\end{array}$ & $\begin{array}{c}0.456 \\
(0.788)\end{array}$ & $\begin{array}{c}0.185 \\
(0.001)\end{array}$ \\
\hline SEC & $\begin{array}{l}0.146 \\
(0.01)\end{array}$ & $\begin{array}{c}0.553 \\
(0.766)\end{array}$ & $\begin{array}{c}0.308 \\
(0.706)\end{array}$ \\
\hline TFPC & $\begin{array}{c}0.205 \\
(0.233)\end{array}$ & $\begin{array}{c}0.422 \\
(0.245)\end{array}$ & $\begin{array}{c}0.882 \\
(0.003)\end{array}$ \\
\hline \multicolumn{4}{|l|}{ Panel B: 1997} \\
\hline TEC & $\begin{array}{c}0.237 \\
(0.118)\end{array}$ & $\begin{array}{c}0.334 \\
(0.788)\end{array}$ & $\begin{array}{c}0.118 \\
(0.002)\end{array}$ \\
\hline $\mathrm{TC}$ & $\begin{array}{l}0.201 \\
(0.05)\end{array}$ & $\begin{array}{l}0.138 \\
(0.03)\end{array}$ & $\begin{array}{c}0.127 \\
(0.005)\end{array}$ \\
\hline PEC & $\begin{array}{c}0.234 \\
(0.046)\end{array}$ & $\begin{array}{c}0.179 \\
(0.233)\end{array}$ & $\begin{array}{c}0.873 \\
(0.110)\end{array}$ \\
\hline SEC & $\begin{array}{c}0.115 \\
(0.344)\end{array}$ & $\begin{array}{c}0.788 \\
(0.566)\end{array}$ & $\begin{array}{c}0.432 \\
(0.215)\end{array}$ \\
\hline TFPC & $\begin{array}{c}0.075 \\
(0.803)\end{array}$ & $\begin{array}{c}0.236 \\
(0.455)\end{array}$ & $\begin{array}{c}0.576 \\
(0.012)\end{array}$ \\
\hline \multicolumn{4}{|l|}{ Panel C: 2003} \\
\hline TEC & $\begin{array}{l}0.654 \\
(0.01)\end{array}$ & $\begin{array}{c}0.765 \\
(0.212)\end{array}$ & $\begin{array}{c}0.321 \\
(0.056)\end{array}$ \\
\hline $\mathrm{TC}$ & $\begin{array}{l}0.655 \\
(0.01)\end{array}$ & $\begin{array}{c}0.466 \\
(0.312)\end{array}$ & $\begin{array}{c}0.182 \\
(0.213)\end{array}$ \\
\hline PEC & $\begin{array}{l}1.115 \\
(0.236)\end{array}$ & $\begin{array}{c}0.895 \\
(0.023)\end{array}$ & $\begin{array}{c}0.193 \\
(0.165)\end{array}$ \\
\hline SEC & $\begin{array}{c}2.172 \\
(0.119)\end{array}$ & $\begin{array}{c}0.896 \\
(0.024)\end{array}$ & $\begin{array}{c}0.466 \\
(0.344)\end{array}$ \\
\hline TFPC & $\begin{array}{c}0.931 \\
(0.346)\end{array}$ & $\begin{array}{c}0.269 \\
(0.0342)\end{array}$ & $\begin{array}{c}0.877 \\
(0.313)\end{array}$ \\
\hline
\end{tabular}




\begin{tabular}{|c|c|c|c|}
\hline Test statistics ${ }^{a}$ & $\begin{array}{c}\text { ANOVA } \\
\text { F }(\text { prob }>\text { F })\end{array}$ & $\begin{array}{l}\text { Wilcoxon } \\
\mathrm{z}(\text { prob }>\mathrm{z})\end{array}$ & $\begin{array}{c}\text { Krusal-Wallis } \\
\chi^{2}\left(\text { prob }>\chi^{2}\right)\end{array}$ \\
\hline \multicolumn{4}{|l|}{ Panel D: 2008} \\
\hline TEC & $\begin{array}{c}0.030 \\
(0.788)\end{array}$ & $\begin{array}{l}0.0988 \\
(0.431)\end{array}$ & $\begin{array}{c}0.932 \\
(0.122)\end{array}$ \\
\hline TC & $\begin{array}{c}0.567 \\
(0.345)\end{array}$ & $\begin{array}{c}0.677 \\
(0.002)\end{array}$ & $\begin{array}{c}0.244 \\
(0.236)\end{array}$ \\
\hline PEC & $\begin{array}{c}0.054 \\
(0.536)\end{array}$ & $\begin{array}{l}0.0478 \\
(0.201)\end{array}$ & $\begin{array}{c}0.788 \\
(0.366)\end{array}$ \\
\hline SEC & $\begin{array}{c}2.33 \\
(0.113)\end{array}$ & $\begin{array}{c}0.780 \\
(0.023)\end{array}$ & $\begin{array}{c}0.780 \\
(0.234)\end{array}$ \\
\hline TFPC & $\begin{array}{c}0.476 \\
(0.532)\end{array}$ & $\begin{array}{c}0.762 \\
(0.011)\end{array}$ & $\begin{array}{c}0.566 \\
(0.452)\end{array}$ \\
\hline
\end{tabular}

a Tets methodology follows Elyasiani \& Mehdian (1992).

All tests applied with ownership as grouping variable. The ANOVA is a parametric test that test the null hypothesis that foreign invested and domestic banks have the same mean; Wilcoxon Rank-Sum, Kruskal-Wallis are non-parametric tests that test the shift in the location of the distribution.

The numbers in paranthesis are the p-values associated with the relevant test.

Notes: TEC: technical efficiency changes; TC: technological change; PEC: pure efficinency change; SEC: scale efficiency change; TFPC: total factor productivity change.

Table 4. Summary of parametric and non-parametric tests

\subsection{DEA-Malmquist findings: Country level analysis}

Table 5 presents the Malmquist TFPC estimates applying the intermediation approach by Sealey \& Lindley (1977). In the last column, if the value is greater than one it indicates productivity growth, while a value less than one indicates a TFP decline over the relevant period. We report TFPC decomposed into TEC, TC, PEC and SEC as in Casu et al. (2004), Isik \& Hassan (2003), Delis et al. (2008), and Dogan \& Fausten (2003). This helps to isolate contributions of each component on TFPC. The annual results are geometric means, and indices of change are calculated relative to the previous year using successive reference technologies. If there is increasing returns to scale (IRS) where SEC $>1$ than it is optimal to expand the scale of production in order to increase productivity, whilst decrease the production level if there is DRS, i.e. SEC $<1$ (Isik \& Hassan, 2003).

The results suggests that the average bank experienced a productivity growth of 0.6 per cent, comprising an average technical efficiency increase of 2.4 per cent, a slight average technological decline of 1.8 per cent and an average scale efficiency progress of 1.9 per cent over the 1992-2008 period. TFPC vary across the sample period with a negative change of 40.9 per cent from 1992-93 to 1993-94 attributable to the economic contraction due to the 1994 crisis, which affected the Turkish banking sector badly. In contrast, TEC experienced only 27.7 per cent decline over the same period. Followingly, an immediate recovery of 30.3 per cent is observed in TFPC during 1994-95, while the impact of the 1994 crisis affected TEC by a negative change of 16.1 per cent over the same period. We monitored frequent fluctuations in the TFPC scores of the banks under analysis with the most devastating productivity recessions during 1993-94, 1996-97 and 2000-01. 


\begin{tabular}{llllll}
\hline \multicolumn{1}{c}{ Years } & TEC & TC & PEC & SEC & TFPC \\
\hline $1992-1993$ & 1.339 & 0.826 & 1.027 & 1.304 & 1.106 \\
$1993-1994$ & 1.062 & 0.656 & 0.962 & 1.105 & 0.697 \\
$1994-1995$ & 0.901 & 1.109 & 0.947 & 0.952 & 1.000 \\
$1995-1996$ & 1.003 & 1.127 & 1.001 & 1.002 & 1.130 \\
$1996-1997$ & 1.030 & 0.666 & 1.041 & 0.989 & 0.686 \\
$1997-1998$ & 1.110 & 0.656 & 1.117 & 0.994 & 0.728 \\
$1998-1999$ & 0.875 & 0.912 & 0.946 & 0.926 & 0.798 \\
$1999-2000$ & 1.092 & 1.245 & 1.069 & 1.022 & 1.359 \\
$2000-2001$ & 1.053 & 0.541 & 1.012 & 1.041 & 0.569 \\
$2001-2002$ & 0.885 & 1.380 & 0.863 & 1.026 & 1.221 \\
$2002-2003$ & 0.965 & 1.357 & 1.011 & 0.954 & 1.309 \\
$2003-2004$ & 0.917 & 1.305 & 0.968 & 0.947 & 1.196 \\
$2004-2005$ & 0.965 & 1.888 & 0.984 & 0.981 & 1.822 \\
$2005-2006$ & 1.053 & 0.990 & 1.113 & 0.947 & 1.043 \\
$2007-2007$ & 1.239 & 0.814 & 1.045 & 1.186 & 1.008 \\
$2007-2008$ & 1.001 & 1.113 & 1.000 & 1.001 & 1.114 \\
Mean & 1.024 & 0.982 & 1.005 & 1.019 & 1.006 \\
\hline
\end{tabular}

Notes: 1 = 100 per cent; TEC: technical efficiency change; TC: technological change; PEC: pure efficiency change; SEC: scale efficiency change; TFPC: total factor productivity change.

Table 5. DEA-Malmquist components, 1992-2008 (1=100 per cent)

Starting with 1996, banks in the sample experienced a negative TFPC until 1999 followed by a one year productivity growth in the 1999-2000 period. We suggest the negative trend over 1996-99 period as a contagion effect of Russian crisis in 1998 as it is one of the largest trade partners of Turkey. Attributable to the twin crises of 2000-01, TFPC was negative which suggests the fact that banks could not cope with the changing economic and technological environment that arose from the twin crises and know-how transferred into the system by foreign investors; and since then TFPC between any successive years is consistently positive.

The significant positive TFPC starting in 2001-02 period may be correlated with the signing of the tough IMF recovery program in 2002, and entry of foreign banks into the system, for instance sale of Demirbank to HSBC, and acquisition of Kocbank with UniCredito during 2001 and 2002, respectively. In connection with Eller et al. (2005) this may be the result of better management of financial resources to high return projects, technical progress and better risk diversification of foreign-invested banks. For instance, 
during 2003-04, the productivity growth (19.6 per cent) was primarily the result of technological progress, TC (30.5 per cent) that was partly offset by technical inefficiency (8.3 per cent). Taken together, these results suggest that unproductive banks tend to catch up with productive banks largely in terms TC as banks experienced recessions in their TEC estimates. Over the analysis period, we suggest that the predominant source of TFPC is TC confirmed by the significantly positive Pearson and Kendall's correlation coefficients introduced in Table 6.

\begin{tabular}{lccccc}
\hline & TEC $^{\mathbf{b}}$ & TC $^{\mathbf{b}}$ & PEC $^{\mathbf{b}}$ & SEC $^{\mathbf{b}}$ & TFPC $^{\mathbf{b}}$ \\
\hline TEC & & & & & \\
$\mathbf{p}$ & $1.0000^{* * *}$ & & & \\
$\mathbf{k}$ & $1.0000^{* * *}$ & & & \\
\hline TC & & & & \\
$\mathbf{p}$ & $0.2617^{* * *}$ & $1.0000^{* * *}$ & & \\
$\mathbf{k}$ & $-0.1785^{* *}$ & $1.0000^{* * *}$ & & & \\
\hline
\end{tabular}

\section{PEC}

$\begin{array}{llll}\mathbf{p} & 0.7114^{* * *} & -0.0561^{*} & 1.0000^{* * *} \\ \mathbf{k} & 0.5530^{* * *} & -0.0383^{*} & 1.0000^{* * *}\end{array}$

\begin{tabular}{llllll}
\hline SEC & & & & & \\
$\mathbf{p}$ & $0.5134^{* * *}$ & $-0.2567^{* *}$ & $-0.080^{* * *}$ & $1.0000^{* * *}$ & \\
$\mathbf{k}$ & $0.3793^{* * *}$ & $-0.1720^{* *}$ & $-0.0538^{* *}$ & $1.0000^{* * *}$ & \\
\hline TFPC & & & & & \\
$\mathbf{p}$ & $0.4253^{* * *}$ & $0.6962^{* * *}$ & $0.4362^{* * *}$ & $0.0561^{* * *}$ & $1.0000^{* * *}$ \\
$\mathbf{k}$ & $0.2922^{* *}$ & $0.5292^{* * *}$ & $0.2891^{* * *}$ & $0.0367^{* * *}$ & $1.0000^{* * *}$ \\
\hline
\end{tabular}

a Parametric ordinary Pearson (p) correlation coefficients - first rows of each cell. Kendall's (k) correlation coefficients-second rows of each cell.

$\mathrm{b}$ TEC $=$ Technical efficiency change, $\mathrm{TC}=$ Technological change, $\mathrm{PEC}=$ Pure efficiency change, $\mathrm{SEC}=$ Scale efficiency change, TFPC $=$ Total factor productivity change,

$*{ }^{* *}$ and ${ }^{* * *}$ indicate significance levels of $10 \%, 5 \%$ and $1 \%$, respectively.

Table 6. Pearson and Kendall's rank order correlation coefficients

The null hypothesis is that the correlation coefficient between two variables is zero. In all cases, the Pearson (p) coefficient results confirm all the relationships found with the Kendall's (k) in the direction (positive or negatave) and significance. All of the DEAMalmquist decomposed components, namely, TEC, TC, PEC and SEC, are positively correlated with TFPC ( $\mathrm{p}_{\text {TFPC-TEC }}=0.4253, \mathrm{p}_{\text {TFPC-TC }}=0.6962, \mathrm{p}_{\text {TFPC-PEC }}=0.4362, \mathrm{p}_{\text {TFPC-SEC }}=0.0561$, respectively). TC and PEC are highly positively and statistically significantly associated with TFPC indicating the dominant effect of technological change and managerial efficiency change on the overall productivity scores of banks. TEC is more related to PEC and SEC than to TC ( $\mathrm{p}_{\text {TEC-PEC }}=0.7114, \mathrm{p}_{\text {TEC-SEC }}=0.5134$, $\mathrm{p}_{\text {TEC-TC }}=0.2617$, respectively), confirming the dominant effect of managerial efficiency and scale efficiency in determining the technical 
efficiency of the Turkish commercial banks. This finding also confirms a similar statement by Isik \& Hassan (2002).

It can be stated that, high-tech investments played a crucial role in the positive TC of banks and also on productivity growth over the analysis period. We suggest this as the result of rapid spread of Automatic Telling Machines (ATMs), Point on Sale (POS) terminals and increased number of bank cards issued as a reflection of the widespread acceptance gained by these products. High-tech investments brought into the system by foreign-invested banks is suggested to play a crucial role on positive TC shifting the frontier upwards.

Moreover, significantly positive and high managerial efficiency (PEC) since 2005-06 period can be attributable to the argument that foreign invested banks may increase the quality of human capital in a banking system, either by importing high skilled bank managers to work in their branches or by training the local employees (Lensink \& Hermes, 2004). The DEAMalmquist results also indicated a trade-off between managerial efficiency and technical progress over the period of analysis, which could be explained by the fact that technology transfer through FDI takes time to materialise as resources have to be devoted to learning during which time banks seek ways of attaining gains in terms of managerial or scale efficiency.

\subsection{DEA-Malmquist findings: Bank level analysis}

Our findings in Table 7 suggest that over the 1992-2008 period, foreign-invested banks achieved higher average TFP growth than average of 0.6 per cent for the whole commercial banks in the sample. The highest average achievements in TFPC are experienced by foreigninvested Akbank (investment by Citibank), YKB-UniCredito (earlier Kocbank), Sekerbank (investment by BTA) and Garanti bank (investment by GECC), which are well above the average. Koçbank presented the highest average productivity growth (39 per cent) - prior to the acqusition by YKB. Looking at the figures, we observe that Kocbank experienced the highest average TFPC and TC over the analysis period.This can be attributable to its high level of performance from 2000-01 to 2002-03. This period coincides with the point in time of its merger with the Italian bank, UniCredito, in 2002.

Annual TFPC scores of Dişbank have been the most volatile of all. It has presented a pattern of great sensitivity to macroeconomic and policy changes in the country, which can be a sign that it was not as powerful a bank as were its counterparts under focus. It's most recent recovery (31 per cent) was identified after its sale to one of the most reliable banks of Europe, namely Fortis Bank of Belgium, in 2005. Contrary to the productivity growth experienced during various periods, Kocbank and Disbank experienced productivity decline during the financial crisis periods in the country. We attribute high productivity scores of foreign-invested banks in Turkey to their high level of TC compared to domestic banks. This may suggest that foreign banks which have invested in local Turkish banks have succeeded in utilizing their superior technology and expertise resulting in productivity growth higher than the market average and domestic banks.

The same is applicable for TEC estimates but this time adding Finansbank to the list. In general, TEC results indicate that foreign-invested banks are relatively more efficient (higher postive TEC) than their domestic counterparts consistent with the findings of Hasan \& Hunter (1996), Mahajan et al. (1996), DeYoung \& Nolle (1996) and Chang et al. (1998). 


\begin{tabular}{|c|c|c|c|c|c|}
\hline Bank & TEC & TC & PEC & SEC & TFPC \\
\hline Ziraat Bankası & 0.982 & 0.992 & 0.947 & 1.037 & 0.974 \\
\hline Halk Bankası & 1.046 & 0.985 & 1.002 & 1.043 & 1.031 \\
\hline Vakıflar Bankası & 1.090 & 1.029 & 1.044 & 1.045 & 1.122 \\
\hline Alternatif Bank & 0.985 & 0.951 & 0.985 & 1.000 & 0.937 \\
\hline Anadolu Bank & 0.984 & 0.811 & 0.984 & 1.000 & 0.789 \\
\hline Şekerbank-BTA & 1.062 & 1.005 & 1.040 & 1.021 & 1.067 \\
\hline Tekstil Bank & 1.000 & 0.991 & 0.993 & 1.007 & 0.991 \\
\hline TEB-BNP Paribas & 1.008 & 0.989 & 1.003 & 1.005 & 0.997 \\
\hline Garanti Bankası-GECC & 1.041 & 1.020 & 1.022 & 1.019 & 1.062 \\
\hline Işbankası & 1.040 & 1.015 & 1.004 & 1.036 & 1.056 \\
\hline YKB-UniCredito & 1.036 & 1.002 & 0.997 & 1.039 & 1.038 \\
\hline Akbank-Citibank & 1.064 & 1.001 & 1.038 & 1.026 & 1.065 \\
\hline Koçbank-Unicredit/YKB & 1.031 & 1.347 & 1.030 & 1.002 & 1.390 \\
\hline Dişbank-Fortis & 1.000 & 0.951 & 1.000 & 1.000 & 0.951 \\
\hline Demirbank-HSBC & 1.012 & 0.981 & 0.993 & 1.019 & 0.993 \\
\hline Denizbank-Dexia Bank & 1.000 & 0.777 & 1.000 & 1.000 & 0.777 \\
\hline Finansbank-NBG & 1.031 & 0.952 & 1.000 & 1.031 & 0.981 \\
\hline Mean & 1.024 & 0.982 & 1.005 & 1.019 & 1.006 \\
\hline
\end{tabular}

Notes: TEC: technical efficiency changes; TC: technological change; PEC: pure efficinency change; SEC: scale efficiency change; TFPC: total factor productivity change.

Table 7. DEA-Malmquist decomposed components of individual banks, 1992-2008

Another comment was suggested by Havrylchyk (2006), who emphasize that foreign banks acquire more efficient banks in a banking industry, whilst fail to enhance their efficiency further.

In terms of public ownership, a noteworthy aspect of public banks is related to credit. As a result of the political pressure in Turkey, public banks - Ziraat Bankası, Halk Bankası and Vakıflar Bankası - issued loans more easily than their private counterparts. This helped to increase their level of output making them appear efficient and productive. However, this may not be the case on a risk-adjusted basis, as public banks carry a large number of nonperforming loans. If adjustments to their outputs were made to reflect loan losses, public banks might in fact be found to be less efficient than private banks under examination. Nevertheless, lack of detailed data on bad loans of public banks prevents an in-depth examination of this hypothesis. 
Table 8 presents the pre and post FDI technological change scores of foreign invested banks. Estimates highlighted with bold represents the period of post-FDI. It is observed that except from Denizbank, all foreign invested private banks in Turkey have experienced productivity growth during the pre-FDI periods. This supports the argument that efficiency or productivity is a pre condition to FDI and foreign investors target good performing banks to invest.

\begin{tabular}{lcccccc}
\hline & $\mathbf{1 9 9 2 - 2 0 0 0}$ & $\mathbf{2 0 0 0 - 0 4}$ & $\mathbf{2 0 0 4 - 0 5}$ & $\mathbf{2 0 0 5 - 0 6}$ & $\mathbf{2 0 0 6 - 0 7}$ & $\mathbf{2 0 0 7 - 0 8}$ \\
\hline Sekerbank & 0.933 & 1.254 & 1.274 & 1.07 & $\mathbf{0 . 8 2 3}$ & $\mathbf{0 . 9 9 9}$ \\
TEB & 0.905 & 1.245 & 1.454 & $\mathbf{1 . 0 0 8}$ & $\mathbf{0 . 7 6 6}$ & $\mathbf{1 . 0 1 7}$ \\
Garanti Bankas1 & 0.994 & 1.190 & 1.449 & $\mathbf{1 . 0 2 8}$ & $\mathbf{0 . 7 7 3}$ & $\mathbf{1 . 1 0 2}$ \\
YKB & 0.945 & 1.196 & 1.333 & $\mathbf{1 . 0 3 1}$ & $\mathbf{0 . 7 8 3}$ & $\mathbf{1 . 0 7}$ \\
Akbank & 0.931 & 1.369 & 1.314 & 1.06 & $\mathbf{0 . 8 3 9}$ & $\mathbf{1 . 0 6 5}$ \\
Kocbank & 0.981 & $\mathbf{1 . 1 8 2}$ & $\mathbf{1 . 2 6 2}$ & - & - & - \\
Dişbank & 0.991 & 0.999 & 1.243 & $\mathbf{1 . 1 0 4}$ & $\mathbf{0 . 8 9}$ & $\mathbf{1 . 0 0 2}$ \\
Demirbank & 0.945 & $\mathbf{1 . 0 9 9}$ & $\mathbf{1 . 2 3 7}$ & $\mathbf{1 . 1 0 1}$ & $\mathbf{0 . 9 0 4}$ & $\mathbf{0 . 9 9 9}$ \\
Denizbank & 0.866 & 1.033 & 1.3633 & 0.442 & $\mathbf{0 . 7 7 3}$ & $\mathbf{1 . 0 4 5}$ \\
Finansbank & 0.932 & 1.095 & 1.228 & $\mathbf{1 . 0 8 1}$ & $\mathbf{0 . 8 2 6}$ & $\mathbf{1 . 0 0 3}$ \\
\hline
\end{tabular}

Numbers in bold represents the post-FDI periods.

Table 8. Pre and post-FDI technological change of foreign invested banks

\section{Conclusions}

Employing the input oriented DEA-Malmquist model, we estimate the total factor productivity change scores of 17 Turkish commercial banks over the period 1992-2008 period to study the impact of foreign ownership on total factor productivity change and technological change scores of Turkish banking sector. Over the years under study, empirical results indicate that the productivity scores of the industry consistently fell over the crises years. The mean productivity estimates that we find for foreign invested banks in general are higher than those of domestic banks.

We also decompose the productivity change scores (TFPC) into its technical efficiency change (TEC), technological change (TC), pure efficiency change (PEC) and scale efficiency change (SEC) components. Overall, the decomposed figures indicate that the most significant factor on the TFPC scores is the TC component. The major investments in high tech bank operations shifted the frontier upward, in particular after the entry of foreign banks in the sector. This is due to the fact that foreign involvement created pressure on the Turkish banks as a result of increased competition and forced them to diminish their costs. In particular, Demirbank, which was sold to HSBC in 2001, experienced massive productivity growth in the post-FDI period. Despite its beneficial effects and increased trend since 2005, recorded FDI inflows to Turkey have been exceptionally low compared with 
those of the central and east European countries. The main FDI challenges facing Turkey are determining why FDI inflows have remained so low and how Turkey can increase the inflows to desirable levels.

In particular, stability and trust made Turkey an attracting market for foreign investors giving rise to further economic growth during the recent years. In this respect, Turkey with an increasing population, increasing per capita income and having an advantage of geographical location connecting Europe and Middle East is expected to be a further magnet for foreign investors. Moreover, Turkey is in the EU accession process and Turkish banks are in general smaller in size compared to European counterparts, making them easy to be taken over. Also, the flexibility in the Turkish Banking Law treats both domestic and foreign banks the same and does not put limitations on the share of foreign ownership. All of these important issues can be suggested as the key factors boosting up FDI in the Turkish banking sector.

From the economic perspective, it can be suggested that Turkey's accession to the EU should be related to its size, per capita income, and dependence on agriculture. For the EU, these three factors combine to create a huge immigration potential if migration is let free. Moreover, these factors indicate that Turkey may become the largest recipient of transfers from the EU budget due to its large population, at least under the present rules and policies. As a result of these factors, Turkey will face further challenges from the current EU member countries. Given the fact that its size is almost as big as the total of new member countries (EU-12), Turkey as a single country will have strong voting rights in the European Council. This is a big question mark in the EU's mind whether to approve Turkey's accession or not.

\section{References}

Aitken, B. J. \& Harrison, A. E. (1999). Do Domestic Firms Benefit from Direct Foreign Investment? Evidence from Venezuela. American Economic Review, American Economic Association, Vol. 89, No. 3, pp. 605-618.

Altunbas, Y., Molyneux, P., \& Murphy, N. (1994c). Privatization, efficiency and public ownership in Turkey - An analysis of the banking industry 1991-1993. Unpublished working paper, Institute of European Finance.

Aysan, A.F. \& Ceyhan, S.P. (2008). What determines the banking sector performance in globalized financial markets? The case of Turkey, Physica A, No. 387, pp. 1593-1602.

BAT: Quarterly Statistics by Banks, Banks Association of Turkey, various years http://www.tbb.org.tr

Berg, S., Forsund, F. \& Jansen, E. (1992). Malmquist indices of productivity growth during the deregulation of Norwegian banking, 1980-1989. Scandinavian Journal of Economics, Vol. 94, pp. 211-228.

Berger, A. \& Humphrey, D. (1997). Efficiency of Financial Institutions: International Survey and Directions for Future Research. European Journal of Operational Research, Vol. 98, No.2, pp. 175-212.

Berger, A.N. \& Mester, L.J. (2003). Explaining the dramatic changes in performance of US banks: technological change, deregulation, and dynamic changes in competition. Journal of Financial Intermediation, Vol. 12, pp. 57-95. 
Berger, A.N., \& Mester, L.J. (1997). Inside the black box: What explains differences in the efficiencies of financial institutions?. Journal of Banking E Finance, Vol. 21, pp. 895947.

Berger, A.N., Deyoung, R., Genay, H. \& Udell, G.F. (2000). Globalization of Financial Institutions: Evidence from Cross-Border Banking Performance. Brookings-Wharton Papers on Financial Services, pp. 23-120

Bonin, J.P., Hasan, I., \& Wachtel, P. (2005). Bank performance, efficiency and ownership in transition countries. Journal of Banking \& Finance, Vol. 29, pp. 31-53.

Casu, B., Girardone, C. \& Molyneux, P. (2004). Productivity Change in European Banking: A Comparison of Parametric and Non-parametric Approaches. Journal of Banking $\mathcal{E}$ Finance, Vol. 28, No. 10, pp. 2521-2540

Cavallo, L. \& Rossi, S.P.S. (2002). Do environmental variables affect the performance and technical efficiency of European banking systems? A parametric analysis using the stochastic frontier approach, European Journal of Finance, Vol. 8, pp. 123-146

Caves, D. W. Christensen, L. R. and Diewert, W. E. (1982b). The Economic Theory of Index Numbers and the Measurement of Input, Output and Productivity. Econometrica, Vol. 50, pp. 1393-414.

Chaffai, M. E., Dietch, M., \& Lozano-Vivas, A. (2001). Technological and Environmental Differences in the European Banking Industries. Journal of Financial Services Research, Vol. 19, No. 2/3, pp. 147-62.

Chang, C., Hasan, I., \& Hunter, W. (1998). Efficiency of multinational banks: An empirical investigation. Applied Financial Economics, Vol. 8, pp. 689-696.

Claessens, S., Demirguc-Kunt, A. \& Huizinga, H. (2001). How does foreign entry affect domestic banking markets?. Journal of Banking and Finance, Vol. 25, pp. 891-911.

Coelli, T. (1996), A guide to DEAP version 2.1: a Data Envelopment Analysis (Computer programme). CEPA Working Paper 96/08, Department of Econometrics, University of New England, Armidale, Australia.

Delis, M.D., Staikouras, C.K. \& Varlagas, P. (2008). On the Measurement of Market Power in the Banking Industry. Journal of Business Finance and Accounting, forthcoming.

Demirguc-Kunt, A. \& Huizinga, H. (2000). Determinants of commercial bank interest margins and profitability: Some international evidence. World Bank Economic Review, No. 13, pp. 379-408.

Denizer, C.A., Dinc, M. \& Tarimcilar, M. (2000). Measuring banking efficiency in the preand postliberalisation environment: Evidence from the Turkish banking system. World Bank Working Paper, No. 2476.

DeYoung, R. \& Nolle, D.E. (1996). Foreign-owned banks in the US: Earning market share or buying it?. Journal of Money, Credit and Banking, Vol. 28, pp. 622-636.

Dietsch, M. \& Lozano-Vivas, A. (2000). How the environment determines banking efficiency: a comparison between French and Spanish industries". Journal of Banking $\mathcal{E}$ Finance, Vol. 24, No. 6, pp. 985-1004.

Dogan, E. \& Fausten, D. (2003). Productivity and technical change in Malaysian banking: 1989-1998, Asia-Pacific Financial Markets, Vol. 10, pp. 205-237

Eller, M., Haiss, P. \& Steiner, K. (2005). Foreign direct investment in the Financial Sector: The Engine of Growth, EI Working Paper, No. 69 
Elyasiani, E. \& Mehdian, S. M. (1992). Productive Efficiency Performance of Minority and Nonminority-Owned Banks: A Nonparametric Approach. Journal of Banking and Finance, Vol. 16, pp. 933-948.

Färe, R, Grosskopf, S., Norris, M. \& Zhang, Z. (1994). Productivity Growth, Technical Progress, and Efficiency Change in Industrialized Countries. American Economic Review, Vol. 84, pp. 66-83.

Färe, R., Grifell-Tatjé, E., Grosskopf, S. \& Lovell, C. A. K. (1997b). Biased Technical Change and the Malmquist Productivity Index. Scandinavian Journal of Economics, Vol. 99, No. 1, pp. 119-27.

Farrell, M. J. (1957). The Measurement of Productive Efficiency. Journal of the Royal Statistical Society, Vol. 120, pp. 253-81.

Fries, S. \& Taci, A. (2002). Banking Reform and Development in Transition Economies. EBRD Working Paper, No. 71.

Global Competitiveness Report 2007-2008, World Economic Form: October 312007.

Görg, H. \& Greenaway, D. (2004). Much Ado about Nothing? Do Domestic Firms Really Benefit from Foreign Direct Investment?. World Bank Research Observer, Oxford University Press, Vol. 19, No. 2, pp. 171-197.

Grifell-Tatje, E. \& Lovell, C.A.K. (1997). The sources of productivity change in

Hancock, D., Humphrey, D.B. \& Wilcox, J.A. (1999). Cost reductions in electronic payments: The roles of consolidation, economies of scale and technical change, Journal of Banking and Finance, Vol. 23, pp. 391-421

Hasan, I., \& Hunter, W.C. (1996). Efficiency of Japanese multinational banks in the United States. In: Chen, Andrew H. (Ed.), Research in Finance, Vol. 14. JAI Press, Greenwich, CT and London, pp. 157- 173.

Havrylchyk, O. (2006). Efficiency of the Polish banking industry: foreign versus domestic banks. Journal of Banking and Finance, Vol. 30, pp. 1975-1996

Hymer, S. (1976). The International Operations of National Firms: A Study of Direct Foreign Investment. MIT Press, Cambridge, Massachussets.

Isik, I. \& Hasan, M.K. (2002). Technical, Scale and Allocative Efficiencies of Turkish Banking Industry. Journal of Banking and Finance, Vol. 26, No. 4, pp. 719-766.

Isik, I. (2007). Bank ownership and productivity developments: evidence from Turkey. Studies in Economics and Finance, Vol. 24, pp. 115-139.

Isik, I., \& Hassan, M. K. (2003). Financial disruption and bank productivity: The 1994 experience of Turkish banks. The Quarterly Review of Economics and Finance, Vol. 43, pp. 291-320.

Kraft, E. \& Tirtiroglu, D. (1998). Bank efficiency in Croatia: A stochastic-frontier analysis. Journal of Comparative Economics, Vol. 26, pp. 282-300.

Lensink, R., Meesters, A. \& Naaborg, I. (2008). Bank efficiency and foreign ownership: do good institutions matters?. Journal of Banking and Finance, Vol. 5, pp. 834-44.

Liu, Z. (2008). Foreign direct investment and technology spillovers: theory and evidence. Journal of Development Economics, Vol. 85, pp. 176-93.

Lovell, K. (2001). Future Research Opportunities in Efficiency and Productivity Analysis. Efficiency Series Paper, No. 1, University of Oviedo Department of Economics.

Lozano-Vivas, A., Pastor, J. A. \& Pastor, J. M. (2002). An Efficiency Comparison of European Banking Systems Operating under Different Environmental Conditions. Journal of Productivity Analysis, Vol. 18, pp. 59-77. 
Mahajan, A., Rangan, N. \& Zardkoohi, A. (1996), Cost Structure in Multinational and Domestic Banking. Journal of Banking and Finance, Vol. 20, pp. 283-306.

Malmquist, S. (1953). Index Numbers and Indifference Surfaces. Trabajos de Estatistica, Vol. 4, pp. 209-42.

Mercan, M., Reisman, A., Yolalan, R., \& Emel, A.B. (2003). The effect of scale and mode of ownership on the financial performance of the Turkish banking sector: Results of a DEA based analysis. Socio-Economic Planning Sciences, Vol. 37, No. 3, pp. 185-202.

Mian, A., (2006). The limits of foreign lending in poor countries. The Journal of Finance, Vol. 61, pp. 1465-1505.

Moran, T.H., Graham, E.M. \& Blomstrom, M. (Eds) (2005). Does Foreign Direct Investment Promote Development?. Peterson Institute of International Economics,Washington, DC, May, pp. 440.

Mukerjee, K., Ray, S.C. \& Miller, S.M. (2001). Productivity growth in large US commercial banks: the initial post-deregulation experience. Journal of Banking and Finance, Vol. 25, pp. 913-39.

Oral, M., \& Yolalan, R. (1990). An empirical study on measuring operating efficiency and profitability of bank branches. European Journal of Operational Research, Vol. 46, pp. 282-294.

Pasiouras, F. (2008). International evidence on the impact of regulations and supervision on banks' technical efficiency: an application of two-stage data envelopment analysis. Review of Quantitative Finance and Accounting, Vol. 30, pp. 187-223.

Pasiouras, F., Tanna, S. \& Zopounidis, C. (2007). Regulations, supervision, and banks' cost and profit efficiency around the world: a stochastic frontier approach. working paper series, 2007.05, University of Bath School of Management, Bath.

Ray, S. \& Desli, E. (1997). Productivity Growth, Technical Progress, and Efficiency Change in Industrialized Countries: Comment. American Economic Review, Vol. 87, No. 5, pp. 1033-9.

Rezvanian, R., \& Mehdian, S. (2002). An examination of cost structure and production performance of commercial banks in Singapore. Journal of Banking and Finance, Vol. 26, pp. 79-98.

Sathye, M. (2001). X-efficiency of Australian banking: An empirical investigation. Journal of Banking and Finance, Vol. 25,pp. 613-630.

Sealey Jr., C.W. \& Lindley, J.T. (1977). Inputs, outputs, and a theory of production and cost at depository financial institutions. Journal of Finance, Vol. 32, pp. 1251-1266.

Spanish banking. European Journal of Operational Research, Vol. 5, pp. 257-264.

Stein, J. (2002). Information Production and Capital Allocation: Decentralized versus Hierarchical Firms. Journal of Finance, Vol. LVII, No.5, October 2002.

Steinherr, A., Tukel, A. \& Ucer, M. (2004). The Turkish Banking Sector: Challenges and Outlook in Transition to EU Membership. Bruges European Economic Policy Briefings, No.9.

Tirtiroglu, D., Daniels, K.N. \& Tirtigoglu, E. (2005). Deregulation, Intensity of Competition, Industry Evolution, and the Productivity Growth of U.S. Commercial Banks. Journal of Money, Credit and Banking, Vol. 37, No. 2, pp. 339-360.

Worthington, A.C. (1999). Malmquist indices of productivity change in Australian financial services. Journal of International Financial Markets, Institutions and Money, Vol. 9, pp. 303-320. 
Yildirim, C. (2002). Evolution of banking efficiency within an unstable macroeconomic environment: The case of Turkish commercial banks. Applied Economics, Vol. 34, pp. 2289-2301.

Yolalan, R. (1996). Turk Bankacilik Sektoru icin Goreli Mali Performans Olcumu. Turkiye Bankalar Birligi Bankacilar Dergisi, Vol. 19, pp. 35-40.,

Zaim, O. (1995). The effect of financial liberalisation on the efficiency of Turkish commercial banks. Applied Financial Economics, Vol. 5, pp. 257-264 


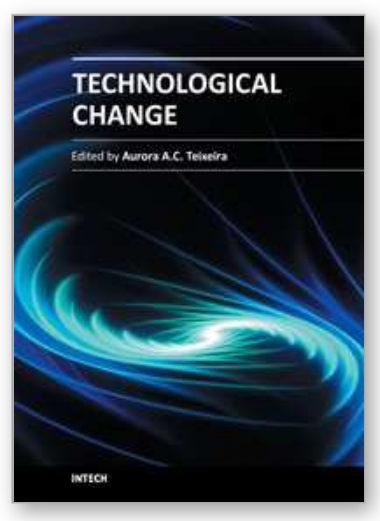

\author{
Technological Change \\ Edited by Dr. Aurora Teixeira
}

ISBN 978-953-51-0509-1

Hard cover, 238 pages

Publisher InTech

Published online 11, April, 2012

Published in print edition April, 2012

Technological change is today central to the theory of economic growth. It is recognised as an important driver of productivity growth and the emergence of new products from which consumers derive welfare. It depends not only on the work of scientists and engineers, but also on a wider range of economic and societal factors, including institutions such as intellectual property rights and corporate governance, the operation of markets, a range of governmental policies (science and technology policy, innovation policy, macroeconomic policy,competition policy, etc.), historical specificities, etc. Given that technology is explicitly taken up in the strategies and policies of governments and firms, and new actors both in the national and international arenas become involved, understanding the nature and dynamics of technology is on demand. I anticipate that this book will decisively contribute in this regard.

\title{
How to reference
}

In order to correctly reference this scholarly work, feel free to copy and paste the following:

Özlem Olgu (2012). Towards the European Union - Impact of FDI and Technological Change on Turkish Banking, Technological Change, Dr. Aurora Teixeira (Ed.), ISBN: 978-953-51-0509-1, InTech, Available from: http://www.intechopen.com/books/technological-change/towards-the-european-union-impact-of-fdi-andtechnological-change-in-turkish-banking

\section{INTECH}

open science | open minds

\author{
InTech Europe \\ University Campus STeP Ri \\ Slavka Krautzeka 83/A \\ 51000 Rijeka, Croatia \\ Phone: +385 (51) 770447 \\ Fax: +385 (51) 686166 \\ www.intechopen.com
}

\author{
InTech China \\ Unit 405, Office Block, Hotel Equatorial Shanghai \\ No.65, Yan An Road (West), Shanghai, 200040, China \\ 中国上海市延安西路65号上海国际贵都大饭店办公楼405单元 \\ Phone: +86-21-62489820 \\ Fax: $+86-21-62489821$
}


(C) 2012 The Author(s). Licensee IntechOpen. This is an open access article distributed under the terms of the Creative Commons Attribution 3.0 License, which permits unrestricted use, distribution, and reproduction in any medium, provided the original work is properly cited. 